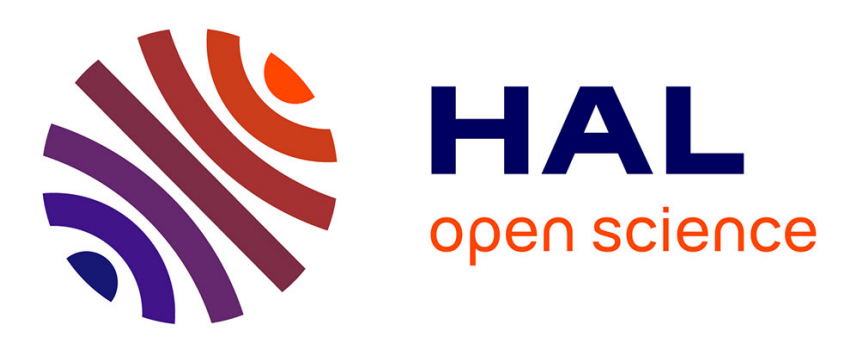

\title{
Valuation of investment projects by an international oil company: A new proof of a straightforward, rigorous method
}

Axel Pierru, Denis Babusiaux

\section{To cite this version:}

Axel Pierru, Denis Babusiaux. Valuation of investment projects by an international oil company: A new proof of a straightforward, rigorous method: Cahiers de l'Economie, Série Recherche, $\mathrm{n}^{\circ} 72.2009$. hal-02469498

\section{HAL Id: hal-02469498 \\ https://hal-ifp.archives-ouvertes.fr/hal-02469498}

Preprint submitted on 6 Feb 2020

HAL is a multi-disciplinary open access archive for the deposit and dissemination of scientific research documents, whether they are published or not. The documents may come from teaching and research institutions in France or abroad, or from public or private research centers.
L'archive ouverte pluridisciplinaire HAL, est destinée au dépôt et à la diffusion de documents scientifiques de niveau recherche, publiés ou non, émanant des établissements d'enseignement et de recherche français ou étrangers, des laboratoires publics ou privés. 


\title{
Valuation of investment projects by an international oil company: A new proof of a straightforward, rigorous method
}

\author{
Axel PIERRU \\ Denis BABUSIAUX
}

February 2009

\section{Les cahiers de l'économie - $\mathbf{n}^{\circ} 72$}

\section{Série Recherche}

axel.pierru@ifp.fr

denis.babusiaux@numericable.fr

La collection "Les cahiers de l'économie" a pour objectif de présenter des travaux réalisés à l'IFP et à l'IFP School, travaux de recherche ou notes de synthèse en économie, finance et gestion. La forme peut être encore provisoire, afin de susciter des échanges de points de vue sur les sujets abordés.

Les opinions émises dans les textes publiés dans cette collection doivent être considérées comme propres à leurs auteurs et ne reflètent pas nécessairement le point de vue de l'IFP ou de l'IFP School.

Pour toute information sur le contenu, prière de contacter directement l'auteur ;

Pour toute information complémentaire, prière de contacter le Centre Économie et Gestion: Tél. 0147527227 


\begin{abstract}
The problem studied is that of valuing investment projects of an international oil company subject to tax schemes that vary from one country to another. The existing disparities in the tax treatment of interest paid can lead the firm to seek an optimal allocation of its debt capacity among the various projects. In this context, the generalized ATWACC (After-Tax Weighted Average Cost of Capital) method presents numerous advantages over standard methods and is particularly well suited to the valuation of oil-field development projects where debt financing differs from the amount that would correspond to the debt ratio targeted by the firm at the corporate scale. In this paper, we discuss adapting the generalized ATWACC method to the specificities of the oil industry and offer new proof of its validity, based on a model that maximizes, under constraints, the firm's equity value.
\end{abstract}




\section{Introduction}

Valuing an investment opportunity in oil and gas exploration-production generally requires the use of approaches - decision trees, sensitivity analyses - designed to take into account the uncertainty and flexibility associated with the project in question. Regardless of the approach taken at a given time, a valuation of the project using deterministic hypotheses is nevertheless inevitable. It is therefore necessary to use a method that allows the project's net present value to be accurately determined by factoring in its financing.

Investment projects are generally valued on the assumption that the firm must comply with a debt ratio $^{1}$ at company level, at least for all projects belonging to a given risk class. This is also the case for a multinational firm investing in various countries. This ratio, called here the "target debt ratio", helps to determine the firm's cost of equity. A multinational firm may, however, wish to capitalize on the fact that some of its subsidiaries have local access to loans for which the after-tax cost is lower than can be obtained elsewhere. This is particularly true of oil companies. In the exploration and production sector, tax schemes are specific and vary greatly from one country to another, and at times even from one oil field to another. For example, in 2007 the tax rate on oil revenue in Norway - ordinary income tax plus special petroleum tax - is $78 \%$, and interest paid to lenders is fully deductible from taxable income (provided that the amounts borrowed do not exceed $80 \%$ of the investment). In Angola, on the other hand, interest associated with loans cannot be recovered under production-sharing agreements. A firm operating in these two countries and seeking to minimize the total amount of taxes paid will therefore borrow more in Norway than in Angola. In reality, an oil company often allocates to a project loans representing more (or less) than the portion corresponding to the target debt ratio that must be complied with at company level (i.e. for all projects).

In this paper ${ }^{2}$, we present and illustrate the generalized ATWACC method, an adaptation of the standard WACC method that can be used to value projects with any debt ratio. This method was proposed by Babusiaux and Pierru (2001a). Here, we prove its validity using a model that maximizes, under constraints, the firm's equity value.

\section{Limitations of project-valuation methods used in the industry}

In the industry, a number of methods are used to value investment projects. Here, we consider projects for which debt financing is included in the calculation of the debt ratio targeted by the firm. The methods traditionally used are therefore the standard WACC method and the BTWACC method. ${ }^{3}$

The standard WACC method entails discounting after-tax operating cash flows ${ }^{4}$ at a rate defined as the firm's after-tax weighted average cost of capital. This calculation reflects the point of view of a department in charge of investment projects for which all financing-related data are included in calculating the discount rate.

In the oil exploration and production sector, the BTWACC method is routinely used ${ }^{5}$. This method reflects the perspective of all the firm's funds providers, since it discounts the total cash flow received - or paid out - by shareholders and debtholders (i.e., the sum of the after-tax operating

\footnotetext{
${ }^{1}$ According to Graham and Harvey (2001), $80 \%$ of firms target a given debt ratio.

2 This is an abbreviated version of an article published in the OPEC Energy Review (2008, 32(3), p. 197-214).

${ }^{3}$ Also called the Arditti-Levy method (1977), the shadow interest method, and, by Ruback (2002), the capital cash flow method.

${ }^{4}$ Here, the term "after-tax operating cash flow" refers to the cash flow of the project before any financial claims are paid. For tax purposes, the taxable income used is defined as the earnings before interest and taxes, which means that the after-tax operating cash flow includes no interest tax shields. Some authors also use the term "free cash flow".

${ }^{5}$ For example, the BTWACC method is the official method of Total.
} 
cash flow and the interest tax shields). The discount rate used is the firm's before-tax weighted average cost of capital. In considering a discount rate independent from taxation, this method is particularly appropriate for an international firm in the upstream oil or gas sector subject to tax schemes that vary greatly from one country to another, and even from one permit to another. These often-complex tax schemes are frequently defined on a contractual basis within the scope of production-sharing agreements or service contracts, and can vary over time.

The use of both these methods is based on the implicit assumption that each year the project's debt ratio is equal to that of the firm. Both methods therefore lead to the same net present value, as illustrated by Chambers et al. (1982). Neither of these methods can be used to value a project whose debt ratio differs, for tax reasons, from that targeted by the firm. The generalized ATWACC method proposed by Babusiaux and Pierru (2001a) meets this objective.

\section{Presentation of the generalized ATWACC method}

\section{Hypotheses and notations}

Let us consider a multinational firm subject to different tax schemes from one country to another. For the sake of simplicity, we assume that all the firm's investment projects belong to the same risk class - for example, that they are all oil-field development projects - and are financed using loans contracted at the same ${ }^{6}$ annual interest rate, denoted as $r$. The firm's cost of equity is denoted as $k_{e}$. All these data, like those that follow, are expressed in nominal dollars.

We assume that with each project $u$ is associated a given stream of after-tax operating cash flows that goes from year 0 to year $T$. The after-tax operating cash flow at year $n$ of project $u$ is denoted as $F_{u, n}$. At each year $n$, the taxable income of project $u$ is subject to a special tax rate, denoted as $\theta_{u, n}$.

We assume a predefined target debt ratio, denoted as $w$, with which the firm must comply. However, the firm may wish to allocate to a project loans representing more (or less) than the portion corresponding to its target debt ratio $w$ (which must be satisfied at company level). In fact, debt financing giving rise to tax shields in a given country depends on the investments made in that country. In particular, the loans associated with oil-field development projects are usually known. As we pointed out above, tax rules, such as those related to the deductibility of interest payments, and applicable tax rates can vary greatly from one project to another. The firm must therefore seek an optimal allocation of its debt.

\section{Optimal allocation of debt among various projects}

In theory, each year the firm must allocate the loans in increasing order of their after-tax $\operatorname{cost}^{7}$ $\left(1-\theta_{u, n}\right) r$. When the total amount of loans available at company level (in compliance with the target debt ratio) is fully used up, the after-tax cost of the last loan allocated therefore corresponds to the firm's marginal cost of debt. If the firm's debt capacity were increased by a dollar, the debt would be contracted at this marginal cost. We denote $t$ as the tax rate that applies to the taxable income of the project to which this (last) loan is allocated. At company level, the after-tax marginal cost of debt is therefore $(1-t) r$ (subsequently assumed to be constant over time).

\footnotetext{
6 This latter assumption can be easily disregarded, as illustrated by Babusiaux and Pierru (2001a).

${ }^{7}$ We must take $\theta_{u, n}=0$ if we consider a concession for which the interest payments are not deductible from the taxable income or a production-sharing agreement for which these payments are not included in cost oil.
} 


\section{The firm's discount rate}

In accordance with standard microeconomic reasoning, the discount rate used by the firm is the firm's marginal cost of capital. As the firm maintains its debt ratio equal to a given target debt ratio, the composition (debt and equity) of the last dollar of capital raised by the firm satisfies this target debt ratio. The firm's marginal cost of capital is therefore a weighted average of the firm's marginal after-tax cost of debt and its cost of equity. In the standard case where the firm faces only a single tax rate, to determine the firm's marginal after-tax cost of debt is not an issue, as the after-tax cost of debt is the same for all projects. Here, the after-tax cost of debt actually paid depends on the project considered. Because of the resulting optimal debt allocation between projects, the firm's marginal after-tax cost of debt to use is $(1-t) r$. The discount rate used here is a WACC computed on a marginal basis. However, unlike the standard case, this WACC discount rate, computed as the weighted average of the firm's marginal financing costs, is here not equal to the weighted average of the firm's average financing costs (that would be obtained by considering the average after-tax cost of debt).

As a result, the cash flows of all the projects must be discounted at the same ${ }^{8}$ rate, $i$, defined as follows:

$$
i=w(1-t) r+(1-w) k_{e}
$$

\section{Net present value of a project}

The net present value of project $u$ is given by the following formula:

$$
F_{u, 0}+\sum_{n=1}^{T} \frac{F_{u, n}+\left(\theta_{u, n}-t\right) r B_{u, n-1}}{(1+i)^{n}}
$$

where $B_{u, n-1}$ is the outstanding amount at the end of year $n-1$ of the debt allocated to project $u$.

The cash flow attributed to the project under consideration is therefore equal each year to the sum of the project's after-tax operating cash flow and an interest-tax-shield differential. The economic interpretation of this differential is as follows: at each year $n-1$, compliance with the firm's target debt ratio $w$ implies that, if loan amount $B_{u, n-1}$ could no longer be allocated to project $u$, it would then be allocated to the project used to define the firm's (after-tax) marginal cost of debt. The corresponding after-tax interest payment would then be $(1-t) r B_{u, n-1}$, instead of $\left(1-\theta_{u, n}\right) r B_{u, n-1}$. Therefore, project $u$ generates the following reduction of after-tax interest payment:

$$
(1-t) r B_{u, n-1}-\left(1-\theta_{u, n}\right) r B_{u, n-1}=\left(\theta_{u, n}-t\right) r B_{u, n-1} \text {. }
$$

\section{Other profitability criteria}

Other criteria that are used in practice - internal rate of return, profitability index, discounted payback period - can also be computed with the generalized ATWACC method. For instance, a project's internal rate of return is the value of $i$ that cancels out the project's net present value given by (2). This return must be compared to the firm's discount rate given by formula (1).

\footnotetext{
${ }^{8}$ The firm's use of a single discount rate implies that the cost of equity is the same for all projects, regardless of their debt ratio, which may appear to contradict the traditional results of finance theory (for example, the formula proposed by Modigliani and Miller (1963)). In fact, this assumption is justified here by the existence of the constraint of compliance with the target debt ratio at company level. This constraint "connects" the projects and results in no differentiation in their cost of equity. Pierru (2008) proves this result by considering the adjusted present values of the various projects.
} 
Adapting the generalized ATWACC method to take into account contractual terms specific to the upstream oil sector does not raise any particular problem.

Let us consider, for example, a project $u$ carried out under a production-sharing agreement, where the interest payment can be recovered in the form of cost oil. One therefore simply regards this interest payment as taking the place of an equivalent amount of profit oil that otherwise would have been shared between the state and the company. At year $n$, the actual gain that results from incorporating this interest payment into the cost oil is therefore $\tau_{u, n} r B_{u, n-1}$, where $\tau_{u, n}$ is the percentage of the profit oil - or, where relevant, the excess oil - accruing to the state at year $n$. The cash flow to be considered with the generalized ATWACC method is therefore:

$$
F_{u, n}+\left(\tau_{u, n}-t\right) r B_{u, n-1} \text {. }
$$

\section{Numerical example}

Let us consider a firm using the generalized ATWACC method that computes its discount rate with the following data (expressed in nominal dollars): $k_{e}=15 \%, r=8 \%, t=35 \%, w=40 \%$. The firm's marginal after-tax cost of debt - determined by the firm's central services as previously described is therefore:

$$
(1-0.35) 8 \%=5.2 \%
$$

According to equation (1), the discount rate used by the firm is thus equal to $11.08 \%$.

The company is studying an investment project which consists of bringing an oil field into production. The earnings produced by this project are subject to a tax rate $\theta_{u}$ of $70 \%$, constant throughout time. We assume that the fiscal system is a concession which allows deductibility of the interest payments from the taxable income.

The project under study has a lifetime of 7 years, the investment outlay ( $\$ 89$ million) being spent in year 0 . The after-tax operating cash flow (i.e., revenue minus operating expenses, royalty and tax on earnings before interest) is assumed to remain constant and equal to $\$ 18$ million each year (from year 1 to year 7). The project is partly financed by a loan of $\$ 70$ million contracted in year 0 at an annual interest rate of $8 \%$. The loan reimbursement is assumed to be 'as fast as possible' as is often the case in practice.

The first step is to compute the schedule of debt reimbursement. For this, it suffices to say that each year the outstanding debt amount will decrease by an amount equal to the difference between the after-tax operating cash flow and the after-tax interest payment (the tax rate considered being 70\%, the effective project's tax rate). The results are given in Table 1.

Table 1

Debt repayment schedule (\$ millions)

\begin{tabular}{|crrrrrrrr|}
\hline Year & 0 & 1 & 2 & 3 & 4 & 5 & 6 & 7 \\
\hline Outstanding debt at the end of the year & 70 & 53.68 & 36.97 & 19.86 & 2.33 & 0 & & \\
\hline After tax operating cash flow & & 18 & 18 & 18 & 18 & 18 & 18 & 18 \\
\hline After tax interest payment & 1.68 & 1.29 & 0.89 & 0.48 & 0.06 & & \\
\hline Principal repayment & 16.32 & 16.71 & 17.11 & 17.52 & 2.33 & & \\
\hline
\end{tabular}

Each year, the differential of interest tax shields is obtained by multiplying the outstanding debt amount at the end of the previous year by:

$$
(0.7-0.35) 8 \%=2.8 \%
$$


The project's cash flow is computed by adding this interest-tax-shield differential to the after-tax operating cash flow. The results are given by Table 2 .

Table 2

Cash flow with the generalized ATWACC method (\$ millions)

\begin{tabular}{|crrrrrrrr|}
\hline Year & 0 & 1 & 2 & 3 & 4 & 5 & 6 & 7 \\
\hline Investment & 89 & & & & & & & \\
\hline After-tax operating cash flow & & 18 & 18 & 18 & 18 & 18 & 18 & 18 \\
\hline Interest-tax-shields differential & & 1.96 & 1.5 & 1.04 & 0.56 & 0.07 & & \\
\hline Cash flow & -89 & 19.96 & 19.5 & 19.04 & 18.56 & 18.07 & 18 & 18 \\
\hline
\end{tabular}

The generalized ATWACC method yields a negative net present value of - \$0.26 million.

To compare this value with that obtained with a non-rigorous computation, let us now assume that the firm uses the BTWACC method. The discount rate is then computed on a before-tax basis:

$$
(0.4 \times 8 \%)+(0.6 \times 15 \%)=12.2 \%
$$

With the BTWACC method, every year, the project's cash flow is obtained by adding the full interest tax shields to the after-tax operating cash flow (Table 3).

\section{Table 3}

Cash flow with the BTWACC method (\$ millions)

\begin{tabular}{|crrrrrrrr|}
\hline Year & 0 & 1 & 2 & 3 & 4 & 5 & 6 & 7 \\
\hline Investment & 89 & & & & & & & \\
\hline After-tax operating cash flow & & 18 & 18 & 18 & 18 & 18 & 18 & 18 \\
\hline Interest tax shield & & 3.92 & 3.01 & 2.07 & 1.11 & 0.13 & & \\
\hline Cash flow & -89 & 21.92 & 21.01 & 20.07 & 19.11 & 18.13 & 18 & 18 \\
\hline
\end{tabular}

The resulting net present value is then $\$ 0.75$ million. This (positive) value is incorrect as here the project's debt ratio is not equal to the debt ratio targeted by the firm, which precludes the use of the BTWACC method.

Babusiaux and Pierru (2005) provide other numerical illustrations of the generalized ATWACC method.

\section{A new proof of the generalized ATWACC method}

Here we propose a new proof of the generalized ATWACC method. This proof is based on the interpretation of the Lagrange multipliers of a mathematical program that maximizes a firm's equity value in the context of our analysis.

\section{Constrained optimization of a firm's equity value}

We consider an international firm involved in the development and production of oil (or gas) fields. The model, which covers a period of $T$ years, maximizes the equity value of the firm at year 0 . The firm has $z$ investment opportunities (i.e., projects) that can be undertaken over this period. The firm has the option of choosing the (non-negative) size $x_{u}$ of each project $P_{u}$, with:

$$
x_{u} \geq 0 \quad u=1, \ldots ., z
$$


This assumption is based on two observations:

- A large oil field is usually developed by an association of several firms that share capital costs (in order to reduce their individual exposure to political risks, for instance); consequently, a given firm can consider a project divisible.

- The decision to develop a large oil field may also include developing smaller surrounding oil fields and the sizing of a collecting pipe (with non-constant returns).

Possible interdependencies between the cash flows of the various projects are not considered in the model. However, even if such interdependencies exist in real-life projects - for instance, the simultaneous development of several oil fields in the same area may give rise to an increase in the corresponding investment costs - their impact on the issue raised here, i.e. the debt allocation process, is likely to be negligible. To sum up, the projects constitute continuous ranges of investment in the model, independent of each other.

The expected after-tax operating cash flow to be produced in year $n(n \in\{0,1, \ldots, T\})$ by project $P_{u}$ $(u \in\{1,2, \ldots, z\})$ is denoted as $F_{u, n}\left(x_{u}\right)$ and is assumed to be differentiable with respect to $x_{u}$. Given these assumptions, to define bounded project sizes simply consider the functions $F_{u, n}\left(x_{u}\right)$ so that, in the neighbourhood of the bounds, the investment cost grows very rapidly (or revenues fall sharply). Certain projects can be undertaken beginning in year 0 , and others in later years. For a project $P_{q}$ starting in year $t$, one should then take $F_{q, k}\left(x_{q}\right)=0$ for $k<t$. The expected terminal value of project $P_{u}$ in year $T$ is given as a function of $x_{u}$ and is denoted as $V_{u, T}\left(x_{u}\right)$.

All of the firm's debt is assumed to be contracted at interest rate $r$. The loan amount expected to be allocated in year $n$ to project $P_{u}$ is denoted as $B_{u, n}$. As we assume that the firm cannot lend capital, we must have:

$$
B_{u, n} \geq 0 \quad n=0, \ldots, T-1, \quad u=1, \ldots ., z
$$

For each project $P_{u}$, the debt-related cash flow in year $n+1$ amounts to $B_{u, n+1}-\left(1+\left(1-\theta_{u, n+1}\right) r\right) B_{u, n}$. The interest payment $r B_{u, n}$ is thus assumed to generate tax shields at tax rate $\theta_{u, n+1}$, which depends on the fiscal rules specific to project $P_{u}$. If the interest payment is neither recoverable nor deductible, as in the Angolan production-sharing contract mentioned in the introduction, then one should simply set out: $\theta_{u, n+1}=0$.

In real-life projects, the amount of debt for which interest payments are deductible from the taxable income cannot exceed a certain limit imposed by local fiscal authorities. This maximum amount can generally be considered a function of the size of the project. For instance, it is equal to $80 \%$ of the 
investment expenditure in a Norwegian oil concession, as discussed in the introduction (certain intricacies of the Norwegian petroleum tax system are here voluntarily ignored). In the model, this maximum loan amount, denoted as $B_{u, n}^{l}\left(x_{u}\right)$, is assumed to be a continuous function, differentiable with respect to $x_{u}$. The following constraints are therefore included in the model:

$$
B_{u, n}-B_{u, n}^{l}\left(x_{u}\right) \leq 0 \quad n=0, \ldots ., T-1, \quad u=1, \ldots ., z
$$

Each constraint of type (5) means that a debt in excess of $B_{u, n}^{l}\left(x_{u}\right)$ generates no interest tax shields and, consequently, has no economic interest for the firm. Therefore, such a debt is not contracted through the optimal debt-allocation process (even if this option were explicitly taken into account in the model).

Let $V_{u, n}$ denote the equity value of project $P_{u}$ at the end of year $n$ (present value at year $n$ of the equity cash flows of project $P_{u}$ after year $n$ ). At any given year, the equity value of the firm is considered as being equal to the sum of the equity values of the entire set of projects undertaken. The firm's total value is equal to the sum of the firm's equity value and debt. As the firm undertakes to satisfy a target debt ratio $w$ on the corporate scale each year, we must have:

$$
\sum_{u=1}^{z} B_{u, n}=w\left(\sum_{u=1}^{z} V_{u, n}+\sum_{u=1}^{z} B_{u, n}\right) \quad n=0, \ldots ., T-1
$$

Or, equally:

$$
\sum_{u=1}^{z} B_{u, n}-\frac{w}{1-w} \sum_{u=1}^{z} V_{u, n}=0 \quad n=0, \ldots ., T-1
$$

The firm's cost of equity is denoted as $k_{e} . V_{u, n}$ is calculated according to the equity residual method on a stand-alone basis (i.e. by imputing to project $P_{u}$ all cash flows related to the loans that are associated with it):

$$
V_{u, n}=\sum_{q=n+1}^{T} \frac{F_{u, q}\left(x_{u}\right)+B_{u, q}-\left(1+\left(1-\theta_{u, q}\right) r\right) B_{u, q-1}}{\left(1+k_{e}\right)^{q-n}}+\frac{V_{u, T}\left(x_{u}\right)}{\left(1+k_{e}\right)^{T-n}}
$$

Equally:

$$
\begin{gathered}
\left(1+k_{e}\right) V_{u, n}-V_{u, n+1}-B_{u, n+1}+\left(1+\left(1-\theta_{u, n+1}\right) r\right) B_{u, n}-F_{u, n+1}\left(x_{u}\right)=0 \quad n=0, \ldots ., T-2 \\
\left(1+k_{e}\right) V_{u, T-1}-V_{u, T}\left(x_{u}\right)-\left(1+\left(1-\theta_{u, T}\right) r\right) B_{u, T-1}-F_{u, T}\left(x_{u}\right)=0
\end{gathered}
$$

Note that $V_{u, n}$ is not subject to a non-negativity constraint, since the value of a project can be negative during certain years. Such is the case, for instance, if the last cash flows of the project correspond to the cost for decommissioning and site rehabilitation of a depleted oil field.

The problem of maximization under constraints with which the firm must contend is therefore written as follows: 


$$
\begin{aligned}
& \operatorname{Max} \sum_{u=1}^{Z}\left(V_{u, 0}+F_{u, 0}\left(x_{u}\right)+B_{u, 0}\right) \\
& \text { s.t. } \begin{cases}(u=1, \ldots ., z) & (n=0, \ldots ., T-1) \quad B_{u, n}-B_{u, n}^{l}\left(x_{u}\right) \leq 0 \\
(u=1, \ldots ., z) & (n=0, \ldots ., T-2) \quad\left(1+k_{e}\right) V_{u, n}-V_{u, n+1}-B_{u, n+1}+\left(1+\left(1-\theta_{u, n+1}\right) r\right) B_{u, n}-F_{u, n+1}\left(x_{u}\right)=0 \\
(u=1, \ldots ., z) & \left(1+k_{e}\right) V_{u, T-1}-V_{u, T}\left(x_{u}\right)-\left(1+\left(1-\theta_{u, T}\right) r\right) B_{u, T-1}-F_{u, T}\left(x_{u}\right)=0 \\
(n=0, \ldots ., T-1) & \sum_{u=1}^{z} B_{u, n}-\frac{w}{1-w} \sum_{u=1}^{z} V_{u, n}=0 \\
(u=1, \ldots ., z) & (n=0, \ldots ., T-1) \quad B_{u, n} \geq 0 \\
(u=1, \ldots ., z) & x_{u} \geq 0\end{cases}
\end{aligned}
$$

\section{Resolution and economic interpretation}

We use Kuhn-Tucker conditions to determine the values of the Lagrange multipliers associated with the various constraints of the problem. Let $\lambda_{u, n}, \mu_{n}, \pi_{u, n}$ and $\pi_{u, T-1}$ be the Lagrange multipliers associated with constraints of type (5), (6), (7) and (8) respectively. To write the dual relations, we do not explicitly consider the Lagrange multipliers associated with the non-negativity constraints of type (3) and (4). By applying the Kuhn-Tucker first-order optimality conditions, we obtain the following dual relations:

$$
\left\{\begin{array}{l}
(u=1, \ldots, z) \quad(n=0, \ldots, T-1) \quad \lambda_{u, n} \geq 0 \\
(u=1, \ldots, z) \quad 1-\pi_{u, 0}\left(1+k_{e}\right)+\frac{w \mu_{0}}{1-w}=0 \\
(u=1, \ldots, z) \quad 1-\lambda_{u, 0}-\pi_{u, 0}\left(1+\left(1-\theta_{u, 1}\right) r\right)-\mu_{0} \leq 0 \\
(u=1, \ldots, z)(n=1, \ldots, T-1) \quad-\pi_{u, n}\left(1+k_{e}\right)+\pi_{u, n-1}+\frac{w \mu_{n}}{1-w}=0 \\
(u=1, \ldots, z)(n=1, \ldots ., T-1) \quad-\lambda_{u, n}-\pi_{u, n}\left(1+\left(1-\theta_{u, n+1}\right) r\right)+\pi_{u, n-1}-\mu_{n} \leq 0 \\
(u=1, \ldots, z) \quad \frac{d F_{u, 0}\left(x_{u}\right)}{d x_{u}}+\sum_{n=0}^{T-1}\left(\pi_{u, n} \frac{d F_{u, n+1}\left(x_{u}\right)}{d x_{u}}+\lambda_{u, n} \frac{d B_{u, n}^{l}\left(x_{u}\right)}{d x_{u}}\right)+\pi_{u, T-1} \frac{d V_{u, T}\left(x_{u}\right)}{d x_{u}} \leq 0
\end{array}\right.
$$

At year 0 as for the following years, debt is allocated in increasing order of the loan's after-tax cost (i.e. by decreasing interest tax shields). The corresponding constraints of type (5) are binding. The project to which the last loan is allocated is denoted as $P_{m_{0}}$ (project used to define the firm's marginal cost of debt at year 0 ). The corresponding constraint (5) is not binding, which gives us $\lambda_{m_{0}, 0}=0$, as well as with $B_{m_{0}, 0}>0$. (Please note that this is the only project that meets both these conditions.) We therefore obtain the following two equations:

$$
\begin{aligned}
& 1-\pi_{m_{0}, 0}\left(1+\left(1-\theta_{m_{0}, 1}\right) r_{m_{0}}\right)-\mu_{0}=0 \\
& 1-\pi_{m_{0}, 0}\left(1+k_{e}\right)+\frac{w \mu_{0}}{1-w}=0
\end{aligned}
$$

Which gives :

$$
\pi_{m_{0}, 0}=\frac{1}{1+(1-w) k_{e}+w\left(1-\theta_{m_{0}, 1}\right) r} \text { and } \mu_{0}=\frac{(1-w)\left(k_{e}-\left(1-\theta_{m_{0}, 1}\right) r\right)}{1+(1-w) k_{e}+w\left(1-\theta_{m_{0}, 1}\right) r}
$$


The values of the Lagrange multipliers associated with the constraints corresponding to the other projects can be deduced from the above equations. Let us first consider the projects to which a loan is allocated at year 0, i.e. the projects for which the constraint of type (5) is binding. Equations (9) and (10) become:

$$
\begin{aligned}
& 1-\pi_{u, 0}\left(1+k_{e}\right)+\frac{w \mu_{0}}{1-w}=0 \\
& 1-\lambda_{u, 0}-\pi_{u, 0}\left(1+\left(1-\theta_{u, 1}\right) r_{u}\right)-\mu_{0}=0
\end{aligned}
$$


Which gives:

$$
\begin{gathered}
\pi_{u, 0}=\pi_{m_{0}, 0} \\
\lambda_{u, 0}=\frac{\left(\theta_{u, 1}-\theta_{m_{0}, 1}\right) r}{1+(1-w) k_{e}+w\left(1-\theta_{m_{0}, 1}\right) r}
\end{gathered}
$$

Projects to which no loan is allocated at year 0 have a Lagrange multiplier, associated with the corresponding constraint of type (5), with a zero value: $\lambda_{u, 0}=0$. We write the corresponding equations (9) and (10):

$$
\begin{aligned}
& 1-\pi_{u, 0}\left(1+k_{e}\right)+\frac{w \mu_{0}}{1-w}=0 \\
& 1-\pi_{u, 0}\left(1+\left(1-\theta_{u, 1}\right) r\right)-\mu_{0} \leq 0
\end{aligned}
$$

The first of these two equations (identical to those above) again indicates that:

$$
\pi_{u, 0}=\pi_{m_{0}, 0}
$$

As for the second, it implies: $\theta_{u, 1} \leq \theta_{m_{0}, 1}$, which is entirely consistent with the debt allocation process described above: at year 0 , no loan will be allocated to a project generating an amount of interest tax shields lower than the amount that would be generated by project $P_{m_{0}}$.

This gives a first result that we will generalize to the following years: the Lagrange multipliers associated with the constraints of type (7) are equal each year to the discount coefficient used in the generalized ATWACC method.

In fact, at year $n$, for any project $P_{u}$, we rewrite equations (11) and (12):

$$
\begin{gathered}
-\pi_{u, n}\left(1+k_{e}\right)+\pi_{u, n-1}+\frac{w \mu_{n}}{1-w}=0 \\
-\lambda_{u, n}-\pi_{u, n}\left(1+\left(1-\theta_{u, n+1}\right) r\right)+\pi_{u, n-1}-\mu_{n} \leq 0
\end{gathered}
$$

Let us consider any two projects, $v$ and $w$. Equation (11) proves that if $\pi_{v, n-1}=\pi_{w, n-1}$, then $\pi_{v, n}=\pi_{w, n}$. Since this hypothesis was verified for year 0 , there is in fact equality of these Lagrange multipliers each year. To determine the value, we will again refer to the project used to define the marginal loan for year $n$ in question, denoted as $P_{m_{n}}$. Once the debt is allocated, the marginal project benefits from a loan without its constraint (5) being active: $\lambda_{m_{n}, n}=0$. The above equations therefore become:

$$
\begin{gathered}
-\pi_{m_{n}, n}\left(1+k_{e}\right)+\pi_{m_{n}, n-1}+\frac{w \mu_{n}}{1-w}=0 \\
-\pi_{m_{n}, n}\left(1+\left(1-\theta_{m_{n}, n+1}\right) r\right)+\pi_{m_{n}, n-1}-\mu_{n}=0
\end{gathered}
$$

Which gives: $\frac{\pi_{m_{n}, n}}{\pi_{m_{n}, n-1}}=\frac{1}{1+(1-w) k_{e}+w\left(1-\theta_{m_{n}, n+1}\right) r}$

And finally, for any project: 


$$
\pi_{u, n}=\frac{1}{\prod_{k=0}^{n}\left(1+(1-w) k_{e}+w\left(1-\theta_{m_{k}, k+1}\right) r\right)}
$$

Moreover, projects other than project $P_{m_{n}}$ benefiting from a loan at year $n$ have their constraint (5) active. Equation (12) then corresponds to an equality, which allows us to write:

$$
\lambda_{u, n}=\pi_{u, n}\left(\theta_{u, n+1}-\theta_{m_{n}, n+1}\right) r=\frac{\left(\theta_{u, n+1}-\theta_{m_{n}, n+1}\right) r}{\prod_{k=0}^{n}\left(1+(1-w) k_{e}+w\left(1-\theta_{m_{k}, k+1}\right) r\right)}
$$

The Lagrange multiplier $\lambda_{u, n}$ is zero for all projects not benefiting from a loan at year $n$.

We can now replace the Lagrange multipliers by their respective values in equation (13): for a realized project benefiting each year from a loan, this equation is written:

$$
\frac{d F_{u, 0}\left(x_{u}\right)}{d x_{u}}+\sum_{n=0}^{T-1} \frac{\frac{d F_{u, n+1}\left(x_{u}\right)}{d x_{u}}+\left(\theta_{u, n+1}-\theta_{m_{n}, n+1}\right) r \frac{d B_{u, n}^{l}\left(x_{u}\right)}{d x_{u}}}{\prod_{k=0}^{n}\left(1+(1-w) k_{e}+w\left(1-\theta_{m_{k}, k+1}\right) r\right)}+\frac{\frac{d V_{u, T}\left(x_{u}\right)}{d x_{u}}}{\prod_{k=0}^{n}\left(1+(1-w) k_{e}+w\left(1-\theta_{m_{k}, k+1}\right) r\right)}=0
$$

The interpretation of this equation is straightforward: the discounted income, determined according to the generalized ATWACC method, of the last euro invested in project $u$ is zero.

There is indeed optimum project dimensioning when the generalized ATWACC method is used. In addition, according to equation (13), a project for which $x_{u}=0$, i.e. an unrealized project, has a negative or zero marginal net present value. The Lagrange multipliers $\pi_{u, n}$ and $\lambda_{u, n}$ can be interpreted as giving the discount coefficients of year $n+1$ in relation to year 0 . The discount rate $i_{n}$ for year $n+1$ to year $n$ is given by:

$$
1+i_{n}=\frac{\pi_{m_{n}, n-1}}{\pi_{m_{n}, n}}=1+(1-w) k_{e}+w\left(1-\theta_{m_{n}, n+1}\right) r
$$

which gives:

$$
i_{n}=(1-w) k_{e}+w\left(1-\theta_{m_{n}, n+1}\right) r
$$

If the cash flow of a project at year $n+1$ were increased by one euro, which would amount to relaxing the corresponding constraint (7), the firm's present value would increase by the amount:

$$
\pi_{u, n}=\frac{1}{\prod_{k=0}^{n}\left(1+i_{k}\right)}
$$

The Lagrange multiplier $\lambda_{u, n}$ also indicates the cash flow adjustment to be taken into account, in the form of an after-tax interest expense differential. In fact, if the corresponding constraint (5) were relaxed by one euro, one euro borrowed would be deducted from the "marginal" project and allocated to the project in question. The firm's cash flow would increase at year $n+1$ by the amount $\left(\theta_{u, n+1}-\theta_{m_{n}, n+1}\right) r$, which therefore corresponds to an increase in the objective function in the amount: $\lambda_{u, n}=\frac{\left(\theta_{u, n+1}-\theta_{m_{n}, n+1}\right) r}{\prod_{k=0}^{n}\left(1+i_{k}\right)}$. 
If we assume that the rate $\theta_{m_{n}, n}$ remains constant and equal to $t$ over the entire period in question, equation (13) becomes:

$$
\frac{d F_{u, 0}\left(x_{u}\right)}{d x_{u}}+\sum_{n=0}^{T-1} \frac{\frac{d F_{u, n+1}\left(x_{u}\right)}{d x_{u}}+\left(\theta_{u, n+1}-t\right) r \frac{d B_{u, n}^{l}\left(x_{u}\right)}{d x_{u}}}{\left(1+(1-w) k_{e}+w(1-t) r\right)^{n+1}}+\frac{\frac{d V_{u, T}\left(x_{u}\right)}{d x_{u}}}{\left(1+(1-w) k_{e}+w(1-t) r\right)^{T}}=0 .
$$

The left-hand-side term of this equation corresponds to formula (2).

\section{Conclusions: theoretical and practical advantages of the method proposed}

A first (theoretical) advantage of the generalized ATWACC method is that it allows the financing decision to be decentralized. In fact, maximizing the value of the project or that of the firm leads to the same decision: a loan will be allocated at year $n-1$ to project $u$ only if $\theta_{u, n} \geq t$, i.e. if the after-tax cost of this loan is favourable (which results in a positive cash flow). Otherwise, allocating a loan to the project reduces its net present value. As the point of view of the project and that of the firm are consistent, the financing decision can therefore, in theory, be delegated to the project managers.

From a practical standpoint, the generalized ATWACC method ${ }^{9}$ is easy to work with, since calculating the projects' cash flows does not depend on the debt ratio, which, at company level, must be complied with for all projects of the same type. Moreover, even if allocation of the debt takes into account qualitative or strategic elements, the generalized ATWACC method remains applicable. Allocation of the debt does not need to be defined exactly; it must merely be possible to determine the marginal loan (over the amount of which the firm has some flexibility).

It should be noted that the tax schemes to which projects outside the Exploration-Production sector are subject are far less variable. In the plausible case where these tax schemes are similar to the ones used to define the firm's marginal cost of debt, the method proposed comes down to the standard WACC method. Its use therefore allows a single criterion for all the business sectors of an oil group, a standard criterion whose use is easier and much more common than that of the BTWACC method.

During the initial studies of a project's profitability, particularly during any discussions between partners, calculations are generally made without considering a loan; in other words, they are based on tables of operating cash flows. Moreover, the ex-post analysis of financial earnings is often conducted by calculating an overall accounting rate of return that concerns all the invested capital (ROCE: Return On Capital Employed). The accounting revenues used for this purpose include neither corresponding interest expense nor tax shields. This ROCE is therefore comparable to an after-tax cost of capital. In addition, an EVA (Economic Value-Added) method is used by defining value creation for a year as the difference between annual accounting revenue (excluding financial items) and capital costs. The latter also include an after-tax average cost of capital. In these cases, the explicit or implicit reference is the standard WACC method and not the BTWACC method. One advantage of the generalized ATWACC method is therefore that it is based on comparable elements.

\footnotetext{
${ }^{9}$ An adaptation of the BTWACC method, consistent with the generalized ATWACC method, has also been proposed by Babusiaux and Pierru (2001a); however, this method is difficult to use in practice, since calculating a project's cash flow requires knowing the project's debt ratio each year.
} 
In this paper we focus on the computation of a project's net present value. Of course, other criteria that are used in practice - internal rate of return, profitability index, discounted payback period - can also be computed with the generalized ATWACC method.

Finally, please note that the BTWACC method may be viewed as a specific case of application of the generalized ATWACC method, one in which the firm's after-tax marginal cost of debt is equal to the before-tax interest rate (i.e. $t=0$ ). For a firm using the BTWACC method, adopting the generalized ATWACC method therefore simply amounts to changing the value of a parameter and not really changing the method. This remark can prove valuable, considering how resistant organizations are to change.

\section{References}

Arditti, F. D., Levy, H., 1977. The weighted average cost of capital as a cut-off rate: a critical analysis of the classical textbook weighted average. Financial Management 6, p. 24-34.

Babusiaux, D., Pierru, A., 2005. Corporate investment decisions and economic analysis. Exercises and case studies. Editions Technip, Paris.

Babusiaux, D., Pierru, A., 2001a. Capital budgeting, investment project valuation and financing mix: methodological proposals. European Journal of Operational Research 135, p. 326-337.

Babusiaux, D., Pierru, A., 2001b. De la solution d'un problème concret (projet d'investissement soumis à une fiscalité spécifique) à une avancée théorique (unicité des méthodes de calcul de valeurs actuelles). Revue Economique 52, p. 717-727.

Chambers, D. R., Harris, R. S., Pringle, J. J., 1982. Treatment of financing mix in analyzing investment opportunities. Financial Management 8, p. 24-41.

Graham, J. R., Harvey, C. R., 2001. The theory and practice of corporate finance: evidence from the field. Journal of Financial Economics 60, p. 187-243.

Modigliani, F., Miller, M. H., 1963. Corporate Income Taxes and the Cost of Capital: a correction. American Economic Review 53, p. 433-443.

Pierru, A., 2008. Financing and valuation of a marginal project by a firm facing various tax rates. Frontiers in Finance and Economics 5(2), p. 56-71.

Ruback, R.S., 2002. Capital cash flows: a simple approach to valuing risky cash flows. Financial Management 31, p. 85-103. 


\section{Déjà parus}

CEG-1. D. PERRUCHET, J.-P. CUEILLE,

Compagnies pétrolières internationales : intégration verticale et niveau de risque.

Novembre 1990

CEG-2. C. BARRET, P. CHOLLET,

Canadian gas exports: modeling a market in disequilibrium.

Juin 1990

CEG-3. J.-P. FAVENNEC, V. PREVOT,

Raffinage et environnement.

Janvier 1991

CEG-4. D. BABUSIAUX,

Note sur le choix des investissements en présence de rationnement du capital.

Janvier 1990

CEG-5. J.-L. KARNIK,

Les résultats financiers des sociétés de raffinage distribution en France 1978-89.

Mars 1991

CEG-6. I. CADORET, P. RENOU,

Élasticités et substitutions énergétiques : difficultés méthodologiques.

Avril 1991

CEG-7. I. CADORET, J.-L. KARNIK,

Modélisation de la demande de gaz naturel dans le secteur domestique : France, Italie, Royaume-Uni 19781989.

Juillet 1991

CEG-8. J.-M. BREUIL,

Émissions de SO2 dans l'industrie française : une approche technico-économique.

Septembre 1991

CEG-9. A. FAUVEAU, P. CHOLLET, F. LANTZ,

Changements structurels dans un modèle économétrique de demande de carburant.

Octobre 1991

CEG-10. P. RENOU,

Modélisation des substitutions énergétiques dans les pays de l'OCDE.

Décembre 1991

CEG-11. E. DELAFOSSE,

Marchés gaziers du Sud-Est asiatique : évolutions et enseignements.

Juin 1992

CEG-12. F. LANTZ, C. IOANNIDIS,

Analysis of the French gasoline market since the deregulation of prices.

Juillet 1992

CEG-13. K. FAID,

Analysis of the American oil futures market.

Décembre 1992

CEG-14. S. NACHET,

La réglementation internationale pour la prévention et l'indemnisation des pollutions maritimes par les hydrocarbures.

Mars 1993 
CEG-15. J.-L. KARNIK, R. BAKER, D. PERRUCHET,

Les compagnies pétrolières : 1973-1993, vingt ans après.

Juillet 1993

\section{CEG-16. N. ALBA-SAUNAL,}

Environnement et élasticités de substitution dans l'industrie ; méthodes et interrogations pour l'avenir.

Septembre 1993

\section{CEG-17. E. DELAFOSSE,}

Pays en développement et enjeux gaziers : prendre en compte les contraintes d'accès aux ressources locales. Octobre 1993

\section{CEG-18. J.P. FAVENNEC, D. BABUSIAUX,*}

L'industrie du raffinage dans le Golfe arabe, en Asie et en Europe : comparaison et interdépendance.

Octobre 1993

\section{CEG-19. S. FURLAN,}

L'apport de la théorie économique à la définition d'externalité.

Juin 1994

\section{CEG-20. M. CADREN,}

Analyse économétrique de l'intégration européenne des produits pétroliers : le marché du diesel en Allemagne et en France.

Novembre 1994

\section{CEG-21. J.L. KARNIK, J. MASSERON,*}

L'impact du progrès technique sur l'industrie du pétrole.

Janvier 1995

\section{CEG-22. J.P. FAVENNEC, D. BABUSIAUX,}

L'avenir de l'industrie du raffinage.

Janvier 1995

\section{CEG-23. D. BABUSIAUX, S. YAFIL, *}

Relations entre taux de rentabilité interne et taux de rendement comptable. Mai 1995

\section{CEG-24. D. BABUSIAUX, J. JAYLET, *}

Calculs de rentabilité et mode de financement des investissements, vers une nouvelle méthode ? Juin 1996

\section{CEG-25. J.P. CUEILLE, J. MASSERON,*}

Coûts de production des énergies fossiles : situation actuelle et perspectives. Juillet 1996

\section{CEG-26. J.P. CUEILLE, E. JOURDAIN,}

Réductions des externalités : impacts du progrès technique et de l'amélioration de l'efficacité énergétique. Janvier 1997

\section{CEG-27. J.P. CUEILLE, E. DOS SANTOS,}

Approche évolutionniste de la compétitivité des activités amont de la filière pétrolière dans une perspective de long terme.

Février 1997

CEG-28. C. BAUDOUIN, J.P. FAVENNEC, Marges et perspectives du raffinage. Avril 1997 
CEG-29. P. COUSSY, S. FURLAN, E. JOURDAIN, G. LANDRIEU, J.V. SPADARO, A. RABL, Tentative d'évaluation monétaire des coûts externes liés à la pollution automobile : difficultés méthodologiques et étude de cas.

Février 1998

CEG-30. J.P. INDJEHAGOPIAN, F. LANTZ, V. SIMON,

Dynamique des prix sur le marché des fiouls domestiques en Europe.

Octobre 1998

CEG-31. A. PIERRU, A. MAURO,

Actions et obligations : des options qui s'ignorent.

Janvier 1999

CEG-32. V. LEPEZ, G. MANDONNET,

Problèmes de robustesse dans l'estimation des réserves ultimes de pétrole conventionnel.

Mars 1999

CEG-33. J. P. FAVENNEC, P. COPINSCHI,

L'amont pétrolier en Afrique de l'Ouest, état des lieux

Octobre 1999

CEG-34. D. BABUSIAUX,

Mondialisation et formes de concurrence sur les grands marchés de matières premières énergétiques : le pétrole.

Novembre 1999

CEG-35. D. RILEY,

The Euro

Février 2000

CEG-36. et 36bis. D. BABUSIAUX, A. PIERRU,

Calculs de rentabilité et mode de financement des projets d'investissements : propositions méthodologiques. Avril 2000 et septembre 2000

CEG-37. P. ALBA, O. RECH,

Peut-on améliorer les prévisions énergétiques ?

Mai 2000

CEG-38. J.P. FAVENNEC, D. BABUSIAUX,

Quel futur pour le prix du brut?

Septembre 2000

ECO-39. S. JUAN, F. LANTZ,

La mise en œuvre des techniques de Bootstrap pour la prévision économétrique : application à l'industrie automobile

Novembre 2000

ECO-40. A. PIERRU, D. BABUSIAUX,

Coût du capital et étude de rentabilité d'investissement: une formulation unique de l'ensemble des méthodes.

Novembre 2000

ECO-41. D. BABUSIAUX,

Les émissions de $\mathrm{CO} 2$ en raffinerie et leur affectation aux différents produits finis

Décembre 2000

ECO-42. D. BABUSIAUX,

Éléments pour l'analyse des évolutions des prix du brut.

Décembre 2000 


\section{ECO-43. P. COPINSCHI,}

Stratégie des acteurs sur la scène pétrolière africaine (golfe de Guinée).

Janvier 2001

\section{ECO-44. V. LEPEZ,}

Modélisation de la distribution de la taille des champs d'un système pétrolier, LogNormale ou Fractale ? Une approche unificatrice.

Janvier 2001

\section{ECO-45. S. BARREAU,}

Innovations et stratégie de croissance externe : Le cas des entreprises parapétrolières.

Juin 2001

ECO-46. J. P. CUEILLE,

Les groupes pétroliers en 2000 : analyse de leur situation financière.*

Septembre 2001

\section{ECO-47. T. CAVATORTA,}

La libéralisation du secteur électrique de l'Union européenne et son impact sur la nouvelle organisation électrique française

Décembre 2001

ECO-48. P. ALBA, O. RECH,

Contribution à l'élaboration des scénarios énergétiques.

Décembre 2001

ECO-49. A. PIERRU,*

Extension d'un théorème de dualité en programmation linéaire : Application à la décomposition de coûts marginaux de long terme.

Avril 2002

\section{ECO-50. T. CAVATORTA,}

La seconde phase de libéralisation des marchés du gaz de l'Union européenne : enjeux et risques pour le secteur gazier français.

Novembre 2002

\section{ECO-51. J.P. CUEILLE, L. DE CASTRO PINTO COUTHINO, J. F. DE MIGUEL RODRÍGUEZ,*}

Les principales compagnies pétrolières indépendantes américaines : caractéristiques et résultats récents.

Novembre 2002

\section{ECO-52. J.P. FAVENNEC,}

Géopolitique du pétrole au début du $\mathrm{XXI}^{\mathrm{e}}$ siècle

Janvier 2003

\section{ECO-53. V. RODRIGUEZ-PADILLA,}

avec la collaboration de T. CAVATORTA et J.P. FAVENNEC,*

L'ouverture de l'exploration et de la production de gaz naturel au Mexique, libéralisme ou nationalisme

Janvier 2003

\section{ECO-54. T. CAVATORTA, M. SCHENCKERY,}

Les majors pétroliers vers le multi énergies : mythe ou réalité ?

Juin 2003

ECO-55. P.R. BAUQUIS,*

Quelles énergies pour les transports au XXI ${ }^{e}$ siècle?

Janvier 2004 
ECO-56. A. PIERRU, D. BABUSIAUX,

Evaluation de projets d'investissement par une firme multinationale : généralisation du concept de coût moyen pondéré du capital et conséquences sur la valeur de la firme.

Février 2004

ECO-57. N. BRET-ROUZAUT, M. THOM,

Technology Strategy in the Upstream Petroleum Supply Chain.

Mars 2005

ECO-58. A. PIERRU,

Allocating the $\mathrm{CO}_{2}$ emissions of an oil refinery with Aumann-Shapley prices.

June 2005

ECO-59. F. LESCAROUX,

Les conséquences économiques de la hausse du prix du pétrole.*

Mai 2006

ECO-60. F. LESCAROUX, O. RECH

L'origine des disparités de demande de carburant dans l'espace et le temps : l'effet de la saturation de l'équipement en automobiles sur l'élasticité revenu.

Juin 2006

ECO-61. C. I. VASQUEZ JOSSE, A. NEUMANN,

Transatlantic Natural Gas Price and Oil Price Relationships - An Empirical Analysis.

Septembre 2006

ECO-62. E. HACHE,

Une analyse de la stratégie des compagnies pétrolières internationales entre 1999 et 2004.

Juillet 2006

ECO-63 F. BERNARD, A. PRIEUR,

Biofuel market and carbon modeling to evaluate French biofuel policy.

Octobre 2006

ECO-64. E. HACHE,

Que font les compagnies pétrolières internationales de leurs profits?

Janvier 2007

ECO-65. A. PIERRU,

A note on the valuation of subsidized Loans - Working paper

Janvier 2007

ECO-66. D. BABUSIAUX, P. R. BAUQUIS,*

Que penser de la raréfaction des ressources pétrolières et de l'évolution du prix du brut?

Septembre 2007

ECO-67. F. LESCAROUX,

Car ownership in relation to income distribution and consumers's spending decisions.

Novembre 2007

ECO-68. D. BABUSIAUX, A. PIERRU,

Short-run and long-run marginal costs of joint products in linear programming

Juin 2008

ECO-69. E. HACHE,

Commodities Markets: New paradigm or new fashion?

Juillet 2008 
ECO-70. D.BABUSIAUX, A. PIERRU,

Investment project valuation: a new equity perspective

Février 2009

ECO-71. O. MASSOL, S. TCHUNG-MING,

Stratégies coopératives dans l'industrie du GNL : l'argument de la rationalisation est-il fondé ? Février 2009

* une version anglaise de cet article est disponible sur demande 